\title{
Relevance of increased serum thyroxine concentrations associated with normal serum triiodothyronine values in hypothyroid patients receiving thyroxine: a case for "tissue thyrotoxicosis"
}

\author{
P E JENNINGS， B P O’MALLEY，K E GRIFFIN， B NORTHOVER，F D ROSENTHAL
}

\begin{abstract}
Fifteen patients receiving standard thyroxine replacement therapy $(100-200 \mu g$ daily) for primary hypothyroidism and who had persistently raised free thyroxine concentrations in their serum were investigated to see whether the dose being given was too high. In addition to the usual thyroid hormone assays systolic time intervals (which indicate left ventricular contractility) were calculated as accurate reflectors of tissue thyroid activity.

All patients showed the expected increased free and total thyroxine concentrations; but mean total and free concentrations of triiodothyronine were normal, while reverse triiodothyronine values were raised. Mean systolic time intervals were significantly reduced as compared with normal and fell within the thyrotoxic range.

Seven patients subsequently had their doses of thyroxine reduced by $50 \mu \mathrm{g}$ daily and were reinvestigated one month later. All showed significant falls in circulating thyroxine and triiodothyronine concentrations and an increase in mean systolic time intervals to the normal range.

In patients receiving thyroxine replacement therapy for primary hypothyroidism a raised serum thyroxine concentration may indicate tissue thyrotoxicosis and should prompt a reduction of the thyroxine dose.
\end{abstract}

\footnotetext{
Leicester Royal Infirmary and Department of Pharmacology, University of Leicester

P E JENNINGS, BM, MRCP, medical registrar

B P O'MALLEY, MA, MRCP, lecturer in clinical pharmacology

K E GRIFFIN, FIMLs, chief medical scientific officer

B NORTHOVER, PHD, principal lecturer in pharmacology

F D ROSENTHAL, MD, FRCP, consultant physician

Correspondence to: $\operatorname{Dr}$ B P O'Malley, Department of Pharmacology, Clinical Sciences Building, Leicester Royal Infirmary, Leicester LE2 7LX.
}

\section{Introduction}

It is well recognised that many hypothyroid patients receiving L-thyroxine replacement therapy have raised serum thyroxine concentrations and a raised free thyroxine index but normal serum triiodothyronine values, and the general consensus has been that such patients appear clinically euthyroid. ${ }^{1-4}$ Reports of normal thyrotrophic hormone responsiveness to thyrotrophin releasing hormone in these patients with high circulating thyroxine concentrations ${ }^{5}$ would be in keeping with this clinical impression, whereas contradictory reports of a flat thyrotrophic hormone response to releasing hormone in such subjects ${ }^{6} 7$ favour the existence of iatrogenic hyperthyroidism.

Clearly the question is whether increases of both the serum thyroxine concentration and the free thyroxine index in a patient receiving thyroxine replacement indicate that the dose being administered is in excess of that patient's physiological requirement. The emergence of systolic time intervals (a measure of left ventricular contractility) as accurate reflectors of tissue thyroid activity ${ }^{8}$ provides a possible means of clarifying the issue.

We have made simultaneous measurements of serum thyroxine, triiodothyronine, reverse triiodothyronine, free thyroxine, and free triiodothyronine concentrations along with systolic time intervals in a group of hypothyroid patients who had repeatedly been shown to have raised serum thyroxine concentrations and normal triiodothyronine values while receiving a steady maintenance dose of thyroxine sodium. Subsequently seven of these patients were reinvestigated after reduction of their thyroxine dose.

\section{Patients and methods}

We studied 15 patients aged 26-65 years with primary hypothyroidism, who were taking $100-200 \mu \mathrm{g}$ thyroxine sodium a day but no other medication. All gave informed consent. All the patients had been taking a constant dose of thyroxine for over six months and had persistently been shown to have raised free thyroxine concentrations (greater than $23 \mathrm{pmol} / \mathrm{l}(1.8 \mathrm{ng} / 100 \mathrm{ml})$ ). None had evidence of any 
Systolic time intervals (STI) and circulating thyroxine (T4), triiodothyronine (T3), free thyroxine, free triiodothyronine, and thyrotrophic hormone (TSH) concentrations in patients with primary hypothyroidism receiving thyroxine replacement therapy

\begin{tabular}{|c|c|c|c|c|c|c|c|c|}
\hline $\begin{array}{l}\text { Case } \\
\text { No }\end{array}$ & $\begin{array}{c}\text { Free T4 } \\
\text { (normal } \\
8-23 \mathrm{pmol} / \mathrm{l})\end{array}$ & $\begin{array}{c}\text { T4 } \\
(\text { normal } \\
54-142 \mathrm{nmol} / \mathrm{l})\end{array}$ & $\begin{array}{c}\text { Free T3 } \\
(\text { normal } \\
3-9 \mathrm{pmol} / \mathrm{l})\end{array}$ & $\begin{array}{c}\text { T3 } \\
(\text { normal } \\
0 \cdot 8-2 \cdot 5 \mathrm{nmol} / \mathrm{l})\end{array}$ & $\begin{array}{c}\text { Reverse T3 } \\
(\text { normal } \\
0 \cdot 15-0.54 \mathrm{nmol} / \mathrm{l})\end{array}$ & $\begin{array}{c}\text { TSH } \\
(\text { normal } \\
0.8-6.0 \mathrm{mIU} / \mathrm{l})\end{array}$ & $\underset{\substack{\text { STI† } \\
0 \cdot 26-0 \cdot 32)}}{\text { STral }}$ & TSH response \\
\hline $\begin{array}{l}1^{*} \\
2 \\
3^{*} \\
4 \\
5 \\
6^{*} \\
7^{*} \\
8^{*} \\
9^{*} \\
10 \\
11 \\
12^{*} \\
13 \\
14 \\
15\end{array}$ & $\begin{array}{l}51 \cdot 8 \\
41 \cdot 2 \\
40 \cdot 7 \\
36 \cdot 6 \\
33 \cdot 0 \\
30 \cdot 3 \\
29 \cdot 7 \\
29 \cdot 2 \\
28 \cdot 2 \\
26 \cdot 0 \\
25 \cdot 7 \\
24 \cdot 8 \\
23 \cdot 7 \\
23 \cdot 7 \\
23 \cdot 5\end{array}$ & $\begin{array}{l}288 \\
254 \\
203 \\
223 \\
216 \\
177 \\
207 \\
148 \\
190 \\
155 \\
147 \\
208 \\
172 \\
130 \\
188\end{array}$ & $\begin{array}{l}6 \cdot 5 \\
7 \cdot 7 \\
7 \cdot 7 \\
6 \cdot 6 \\
5.5 \\
5 \cdot 7 \\
3.9 \\
7 \cdot 3 \\
6 \cdot 2 \\
5 \cdot 4 \\
6 \cdot 2 \\
4 \cdot 9 \\
5 \cdot 7 \\
6 \cdot 6 \\
4.8\end{array}$ & $\begin{array}{l}2.1 \\
2.2 \\
1.9 \\
1.9 \\
1.5 \\
1.8 \\
1.2 \\
1.9 \\
1.6 \\
1.4 \\
1.7 \\
1.7 \\
1.7 \\
1.7 \\
1.6\end{array}$ & $\begin{array}{l}1.30 \\
0.90 \\
0.63 \\
0.80 \\
0.78 \\
0.39 \\
0.80 \\
0.41 \\
0.51 \\
0.54 \\
0.56 \\
0.44 \\
0.40 \\
0.45\end{array}$ & $\begin{array}{l}3 \cdot 8 \\
2.3 \\
1 \cdot 7 \\
2 \cdot 3 \\
2 \cdot 4 \\
1.8 \\
2 \cdot 7 \\
3 \cdot 0 \\
2.5 \\
1.2 \\
5 \cdot 8 \\
2.5 \\
2 \cdot 3 \\
4 \cdot 3 \\
-\end{array}$ & $\begin{array}{l}0.25 \\
0 \cdot 29 \\
0 \cdot 26 \\
0 \cdot 22 \\
0.26 \\
0.29 \\
0.24 \\
0 \cdot 23 \\
0.22 \\
0.27 \\
0.22 \\
0.24 \\
0.24 \\
0.26 \\
0.24\end{array}$ & $\begin{array}{l}\text { Flat } \\
\text { Normal } \\
\text { Flat } \\
\text { Flat } \\
\text { 二 } \\
\text { Flat } \\
\text { Flat } \\
\text { Normal } \\
\text { Flat } \\
\text { Flat } \\
\text { Flat } \\
\text { Flat }\end{array}$ \\
\hline
\end{tabular}

* Patient subsequently reinvestigated after reduction of thyroxine dose.

†Exressed as ratio of pre-ejection period to left ventricular ejection time. $\mathrm{T} 4: 1 \mathrm{nmol} / \mathrm{l} \approx 0.08 \mu \mathrm{g} / 100 \mathrm{ml}$. Free $\mathrm{T} 3: 1 \mathrm{pmol} / 1 \approx 0.65 \mathrm{pg} / \mathrm{ml}$. T3 and reverse T3: $1 \mathrm{nmol} / 1 \approx$ $0.65 \mathrm{ng} / \mathrm{ml}$.

other disease known to affect either the hormone assays or measurement of systolic time intervals.

In all patients blood was sampled at about midday, four to five hours after their usual dose of thyroxine, and this was followed within 30 minutes by estimation of the systolic time intervals. In 11 cases the response of thyrotrophic hormone to $200 \mu \mathrm{g}$ releasing hormone given intravenously was also determined within the same 24 hour period. Blood was separated immediately and stored at $-20^{\circ} \mathrm{C}$ until the completion of the study, at which time all samples were analysed for concentrations of total thyroxine and triiodothyronine, free thyroxine, free triiodothyronine, reverse triiodothyronine, and thyrotrophic hormone on their appropriate single assay runs so as to minimise error. Serum thyroxine, triiodothyronine, and free triiodothyronine concentrations were measured by means of a radioimmunoassay kit supplied by BYK Malincrodt. Serum thyrotrophic hormone was measured by a highly sensitive radioimmunoassay (sensitivity $0.3 \mu \mathrm{U} / \mathrm{ml})^{9}$ after appropriate serum dilution. The systolic time intervals were measured according to the method of Weissler, our exact technique having been detailed elsewhere ${ }^{10}$ (normal range 0.26-0.32 (mean 0.29), $n=200$; thyrotoxic range $<0.26$, hypothyroid range $>0.32$ ). The results obtained were expressed as the ratio of the pre-ejection period to left ventricular ejection time and compared with the mean values obtained in normal subjects by an unpaired $t$ test.

Three months after the initial study seven of the patients attended for further thyroid hormone and systolic time interval measurements, which were repeated one month after their respective doses of thyroxine were lowered by $50 \mu \mathrm{g}$. The results obtained before and after thyroxine reduction were analysed by paired $t$ test.

\section{Results}

The table gives the initial results in the 15 patients ranked in order of their mean free thyroxine values. In keeping with the main criterion for selection of patients the mean free thyroxine concentration was raised at $31.2(\mathrm{SD} 8.2) \mathrm{pmol} / \mathrm{l}(2.4(\mathrm{SD} 0.6) \mathrm{ng} / 100 \mathrm{ml})$ (mean normal value $16.0(4.5) \mathrm{pmol} / 1(1.2(0.3) \mathrm{ng} / 100 \mathrm{ml}) ; \mathrm{p}<$ $0.0005)$, and similarly the mean total thyroxine value was significantly raised at $193.7(42.2) \mathrm{nmol} / 1(15.1(3.3) \mu \mathrm{g} / 100 \mathrm{ml}$ ) (mean normal value $98.0(29.3) \mathrm{nmol} / 1(7.6(2.3) \mu \mathrm{g} / 100 \mathrm{ml}) ; \mathrm{p}<0.0005)$. By contrast, both mean total triiodothyronine $(1.7(0.3) \mathrm{nmol} / 1 ; 1.1(0 \cdot 2) \mathrm{ng} / \mathrm{ml})$ and mean free triiodothyronine values $(6.0(1.1) \mathrm{pmol} / 1 ; 3.9(0.7) \mathrm{pg} /$ $\mathrm{ml}$ ) were not significantly different from their respective mean normal values $(1.6(0.6) \mathrm{nmol} / 1(1.0(0.4) \mathrm{ng} / \mathrm{ml}) ; 5.9(2.0) \mathrm{pmol} / \mathrm{l}(3.8(1.3) \mathrm{pg} /$ $\mathrm{ml})$ ). The mean reverse triiodothyronine concentration was raised at $0.64(0.26) \mathrm{nmol} / 1(0.4(0.17) \mathrm{ng} / \mathrm{ml})$ (mean normal value 0.34 $(0.13) \mathrm{nmol} / \mathrm{l}(0.22(0.08) \mathrm{ng} / \mathrm{ml}) ; \mathrm{p}<0.0005)$. The mean systolic time interval ratio of all subjects studied was significantly reduced at $0.25(\mathrm{SD} 0.02)$ (mean normal value $0.29(0.02) ; \mathrm{p}<0.0005)$. In nine of the 11 subjects studied the thyrotrophic hormone response to thyrotrophin releasing hormone was flat (peak/basal value $<2$ ), whereas in the remaining two subjects the serum thyrotrophic hormone concentration rose normally on stimulation by releasing hormone.

In the seven patients reinvestigated after a reduction in their thyroxine replacement dosage the mean serum thyroxine concentra- tion fell from 212 (SD 45) to 162 (35) $\mathrm{nmol} / 1$ (16.5 (3.5) to 12.6 $(2 \cdot 7) \mu \mathrm{g} / 100 \mathrm{ml})(\mathrm{p}<0.0025)$, mean serum triiodothyronine concentration fell from $1.8(0.2)$ to $1.3(0.3) \mathrm{nmol} / 1(1.2(0.1)$ to 0.8 $(0.2) \mathrm{ng} / \mathrm{ml})(\mathrm{p}<0.0025)$, and mean systolic time interval ratio increased from $0.25(0.02)$ to $0.28(0.03)(p<0.0025)$. All seven subjects were clinically euthyroid and symptom free after the reduction of their thyroxine dosage.

\section{Discussion}

Our results confirm that in patients with primary hypothyroidism who had raised serum thyroxine and free thyroxine concentrations while receiving standard thyroxine replacement therapy, circulating concentrations of triiodothyronine and free triiodothyronine were within their respective normal ranges, whilst reverse triiodothyronine values were raised. The mean systolic time intervals of the subjects were significantly reduced as compared with normal, thus falling into the thyrotoxic range. Of the 11 patients tested with thyrotrophin releasing hormone, nine exhibited a flat response of thyrotrophic hormone, the remaining two having normal responsiveness.

We subsequently reinvestigated seven of the original patients after reducing their thyroxine replacement therapy by $50 \mu \mathrm{g}$. The mean thyroxine concentration fell but remained just above the upper limit of normal. The mean systolic time intervals, however, increased to well within the normal range. Despite a fall in mean serum triiodothyronine concentration this also remained within the normal range.

We have therefore shown that in patients with primary hypothyroidism receiving thyroxine replacement therapy the high serum thyroxine concentration is often associated with tissue thyrotoxicosis as assessed by cardiovascular and pituitary responses. Reduction of the dose of thyroxine with subsequent lowering of the serum thyroxine concentration returns the cardiac responses to normal.

The paradox arising from our results is the association of the normal triiodothyronine value with pituitary and cardiovascular responses compatible with thyrotoxicosis. It has to be considered that peripheral conversion of thyroxine to triiodothyronine ${ }^{11}$ may account for our findings. In that case it is surprising that the circulating triiodothyronine concentrations did not rise. Alternatively we may be witnessing a direct effect of raisèd thyroxine concentrations. Interestingly, two subjects had normal thyrotrophic hormone responses to releasing hormone despite high circulating thyroxine concentrations, which may reflect unsuppressible thyrotrophic hormone drive. ${ }^{12}$

We conclude that in patients with primary hypothyroidism receiving thyroxine replacement therapy a raised circulating thyroxine value may be indicative of tissue thyrotoxicosis and should prompt the lowering of the thyroxine dose.

We thank Caroline Parker for typing the manuscript. 


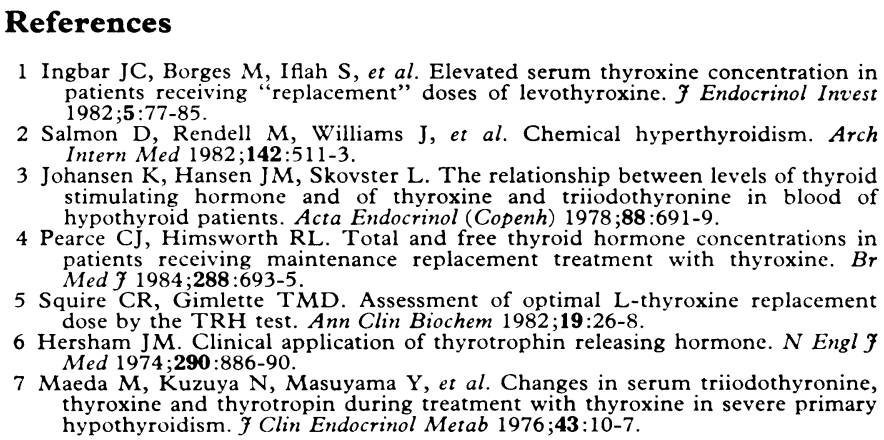

1 Ingbar JC, Borges $M$, Iflah S, et al. Elevated serum thyroxine concentration in patients receiving "replacement" doses of levothyroxine. $\mathcal{F}$ Endocrinol Inves $1982 ; 5 ; 77-85$.

2 Salmon D, Rendell M, Williams J, et al. Chemical hyperthyroidism. Arch Intern Med 1982;142:511-3.

3 Johansen K, Hansen JM, Skovster L. The relationship between levels of thyroid stimulating hormone and of thyroxine and triiodothyronine in blood of hypothyroid patients. Acta Endocrinol (Copenh) 1978;88:691-9. earce CJ, Himsworth RL. Total and free thyroid hormone concentrations in patients receiving maint $1984 ; \mathbf{2 8 8}: 693-5$
Med

5 Squire CR, Gimlette TMD. Assessment of optimal L-thyroxine replacement dose by the TRH test. Ann Clin Biochem 1982;19:26-8. Hersham JM. Clinical application of thyrotrophin releasing hormone. $N$ Engl f
Med 1974;290:886-90.

7 Maeda M, Kuzuya N, Masuyama Y, et al. Changes in serum triiodothyronine, thyroxine and thyrotropin during treatment with thyroxine in severe primary
hypothyroidism. $\mathcal{F}$ Clin Endocrinol Metab $1976 ; 43: 10-7$.

8 Plotnick GD, Vassar DL, Parisi AF, Hamilton BP, Carliner NH, Fisher HL. Systolic time intervals in hypothyroidism; end organ function as a reflection of clinical status. $A m \mathcal{F} M e d ~ S c i$ 1978;277:263-8.

9 O'Malley BP, Jennings PE, Cook N, Barnett DB, Rosenthal FD. The role of $5-\mathrm{HT}$ in the control of TSH and prolactin release in euthyroid subjects as and and zime

10 Northover B, O'Malley BP, Rosenthal FD. Alterations in systolic time intervals in primary hypothyroidism as a consequence of warming. 7 Clin Endocrinol Metab 1983;56:185-8.

11 Pittman CS, Chambers JB, Read VH. The extrathyroidal conversion rate of thyroxine to triiodothyronine in normal man. $\mathcal{F}$ Clin Invest 1971 ;50:1187-96.

12 Soppi E, Irjala K, Kaihola H-L, Viikari J. Acute effect of exogenous thyroxin dose on serum thyroxine and thyrotrophin levels in treated hypothyroid patients. Scand $\mathcal{F}$ Clin L.ab Invest 1984;44:353-6.

(Accepted 2 October 1984)

\title{
Successful plasma exchange in type 1 leprosy reversal reaction
}

\author{
F LUCHT, G RIFLE, H PORTIER, J M CHALOPIN, J BONHOMME
}

\begin{abstract}
A 24 year old man admitted to hospital with borderline lepromatous leprosy was treated with rifampicin, dapsone, and clofazimine. After four months he developed a reversal reaction and the diagnosis was modified to borderline tuberculoid leprosy. The dose of clofazimine was raised and prednisolone added to the regimen without any symptomatic response. His condition improved dramatically after five plasma exchanges on five successive days.
\end{abstract}

\section{Introduction}

The clinical features of leprosy may alter as the patient's immune response to the disease alters. An increase in immunity -termed reversal-is common after treatment, and the disease moves towards the tuberculoid pole. In the type 1 leprosy reversal reaction severe nerve lesions may occur ${ }^{1}$ and are usually controlled by clofazimine and steroids. The failure of this combination in one patient led us to try plasma exchanges.

\section{Case report}

A 24 year old black Senegalese man was first admitted in September 1983 with multiple hypoaesthetic bilateral, symmetrical hypopigmented macules on the neck, face, back, arms, and thighs and nodules on the earlobes. He was found to have symmetrical lesions of the upper branches of the facial, external popliteal, and ulnar nerves and enlargement of the left great auricular nerve. A scraping of the nasal mucosa showed numerous acid fast bacilli. Histopathological examination of an arm lesion showed, below a subepidermal

\footnotetext{
Hôpital du Bocage, Centre Hospitalier et Universitaire, Dijon, France

F LUCHT, MD, assistant, department of infectious and tropical diseases G RIFLE, MD, professor, department of nephrology

H PORTIER, MD, professor, department of infectious and tropical diseases J M CHALOPIN, MD, professor, department of nephrology

J BONHOMME, MD, professor, department of haematology

Correspondence to: Dr F Lucht, Service des Maladies Infectieuses et Tropicales, Hôpital d'Enfants, $10 \mathrm{Bd}$ Marechal-De-Lattre-de-Tassigny,
} BP 1542, 21034 Dijon Cedex, France. clear zone, a focalised granuloma made up of globular and vacuolated histiocytes loaded with viable acid fast bacilli (Ziehl-Neelsen's method) in all the layers of the dermis. Lymphoplasmocytes were sparse. Borderline lepromatous leprosy (Ridley-Jopling classification) was diagnosed.

After four months' treatment with rifampicin $600 \mathrm{mg}$, dapsone $100 \mathrm{mg}$, and clofazimine $100 \mathrm{mg}$ daily he developed increasing oedema, erythema, pain in the pre-existing lesions, and swelling of the affected nerves with diminution of their motor function. Temperature was $38.5^{\circ} \mathrm{C}$. A scraping of the nasal mucosa yielded negative results. Circulating immune complexes were absent. A type 1 leprosy reversal reaction was confirmed by skin biopsy: histopathological examination of a thigh lesion showed a focalised histiocytic granuloma in the middle and deep layers of the dermis, with in the upper layers epithelioid cells, sometimes organised in follicles. Viable acid fast bacilli were less numerous. Borderline tuberculoid leprosy was diagnosed.

On 7 January 1984 the dosage of clofazimine was increased to $400 \mathrm{mg}$ daily and prednisolone $1 \mathrm{mg} / \mathrm{kg}$ was introduced; dosages of rifampicin and dapsone remained as before. His condition did not improve, and the lesions remained painful. From 25 January, on five successive days, he was given five plasma exchanges. At each procedure $150 \%$ of theoretical plasma volume was exchanged for diluted albumin. On the third day his temperature was normal, and by the sixth day the oedema had resolved and the pain disappeared. Nerve paralysis was only slightly improved. Despite antibiotics, clofazimine, and steroids, which were continued in unaltered dosage until $10 \mathrm{March}$, on 17 February he developed a second, identical type 1 leprosy reversal reaction. Plasma exchange as before had a similar effect, after which his condition continued to improve.

\section{Discussion}

Plasma exchange has been used successfully in type 2 reactions (erythema nodosum leprosum) resulting from deposition of immune complexes, ${ }^{2}$ but to our knowledge it has never been used in type 1 reactions. Although results in a single case must be interpreted carefully, such a close relation between plasma exchange and clinical improvement suggests a causal relation.

Usually type 1 leprosy reversal reactions are controlled by clofazimine and steroids. The failure of these drugs in this case may have been due to the fact that rifampicin and dapsone were given in high dosages for a long period. In type 1 leprosy reversal reactions there is an increased phytohaemagglutinin lymphocyte response, which might be explained by a decrease in mycobacterial load in macrophages due to effective antileprosy 